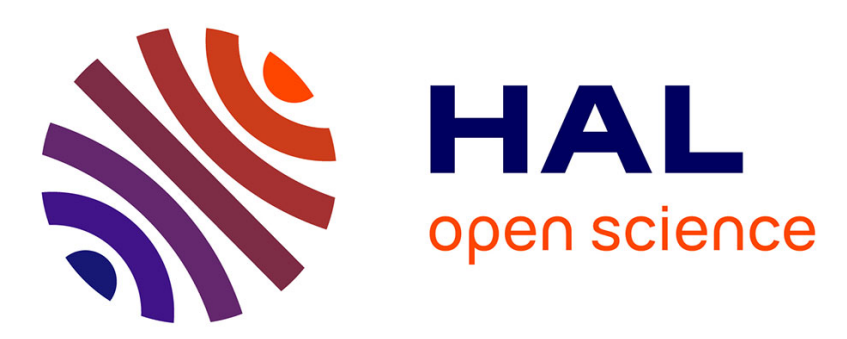

\title{
A glance at the French-speaking diatomist community (ADLaF 2019 meeting)
}

\author{
Martin Laviale, Camille Noûs
}

\section{To cite this version:}

Martin Laviale, Camille Noûs. A glance at the French-speaking diatomist community (ADLaF 2019 meeting). Botany Letters, 2021, 168 (1), pp.3-5. 10.1080/23818107.2020.1779811 . hal-02877132

\section{HAL Id: hal-02877132 \\ https://hal.univ-lorraine.fr/hal-02877132}

Submitted on 22 Jun 2020

HAL is a multi-disciplinary open access archive for the deposit and dissemination of scientific research documents, whether they are published or not. The documents may come from teaching and research institutions in France or abroad, or from public or private research centers.
L'archive ouverte pluridisciplinaire HAL, est destinée au dépôt et à la diffusion de documents scientifiques de niveau recherche, publiés ou non, émanant des établissements d'enseignement et de recherche français ou étrangers, des laboratoires publics ou privés. 


\section{A glance at the French-speaking diatomist community (ADLaF 2019 meeting)}

Martin Laviale ${ }^{\mathrm{a} *}$ and Camille Noûs

${ }^{a}$ Université de Lorraine, CNRS, LIEC, F-57000 Metz, France;

${ }^{b}$ Laboratoire Cogitamus, F-75005 Paris, France

*Author for correspondence: Université de Lorraine, Campus Bridoux, Laboratoire

LIEC, F-57070, Metz, France, martin.laviale@univ-lorraine.fr

To cite this article: Martin Laviale \& Camille Noûs (2020): A glance at the French speaking diatomist community (ADLaF 2019 meeting), Botany Letters, DOI:

$10.1080 / 23818107.2020 .1779811$

This is an Accepted Manuscript of an article published by Taylor \& Francis in Botany Letters on 21/06/2020, available online: http://www.tandfonline.com/10.1080/23818107.2020.177981 
A glance at the French-speaking diatomist community (ADLaF 2019 meeting)

Keywords: diatoms; ecology; ecotoxicology; biomonitoring; taxonomy

\section{Editorial}

The "Association des Diatomistes de Langue Française" (DLaF) is the Frenchspeaking society dedicated to diatom science. Its 38th annual meeting held in September 2019 in Metz (eastern France, ADLaF2019) gathered 64 diatom experts from 8 countries who attended to 30 presentations (including 4 keynote lectures and an outreach event: figure 1) and 8 posters. This editorial refers to some contributions presented during the meeting, either included in this special issue of Botany Letters or published elsewhere. All contributions can be found in the book of abstracts (Laviale et al. 2019b).

a.

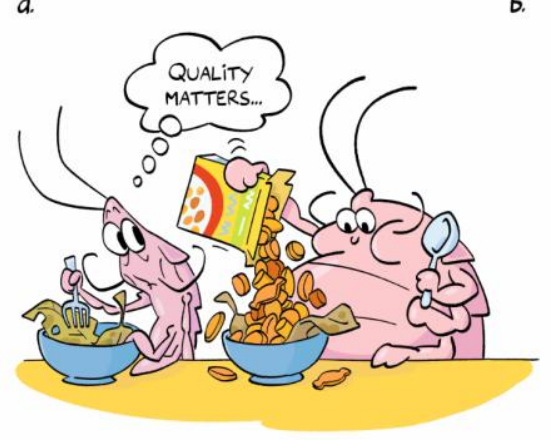

A glance at the 38th ADLaF meeting

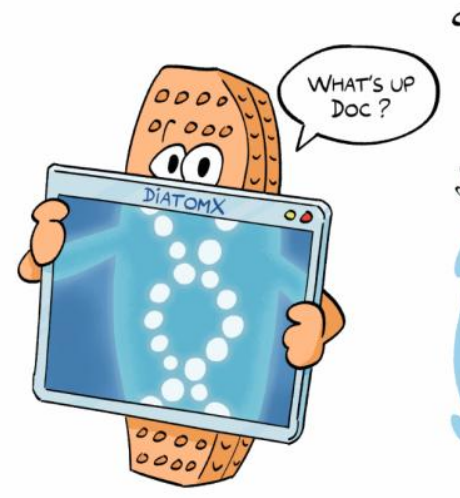

d.

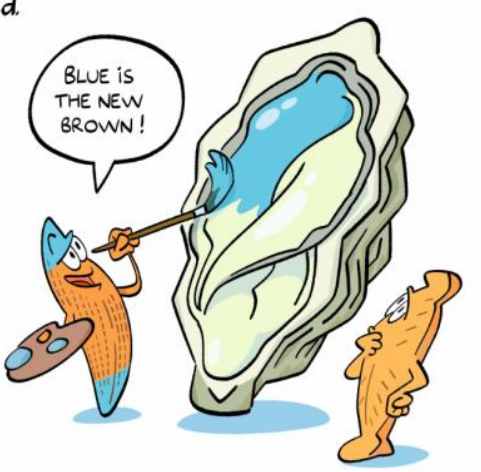

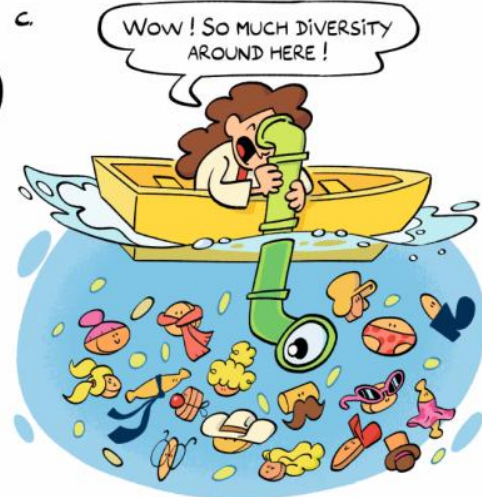

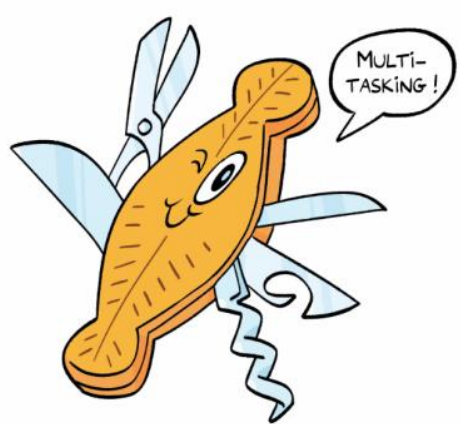

e.

Figure 1. A glance at the 38th ADLaF meeting through the keynote lectures of M. Danger (Université de Lorraine, France: a), F. Larras (UFZ Leipzig, Germany: b), S-D. Ayata (Sorbonne Université, France: c), J-L. Mouget (Le Mans Université, France: d), and a Pint of Science outreach communication by I. Lavoie (INRS-ETE, Canada: e).

A first session dedicated to functional ecology, ecophysiology and ecotoxicology shed 
light on the role of benthic diatoms in forested headwater ecosystems, yet to be clarified. Diatoms have long been considered as minor ecological players with regard to their contribution to carbon and nutrients fluxes. However, recent works have shown that they could be essential for consumers, due to their high nutritional value (e.g. Crenier et al. 2017), but also for microbial decomposers (bacteria and fungi) through complex interactions (Allen et al. 2020). Future works should evaluate the effects of already acting abiotic stressors not only on the cell functioning (Laviale et al. 2019b; Contreras and Gillard 2020) but also on these communities and subsequent consequences for the trophic networks. For this purpose, microbial fatty acids emerge as relevant proxies of ecosystem health (e.g. Fadhlaoui et al. 2020). Among abiotic stressors mentioned during the meeting (pesticides, nanoparticles, natural radioactivity...), the expected increase in frequency and intensity of extreme events due to climate change is a concern shared by both freshwater and marine diatomists: parallel works are ongoing to evaluate the effects of heat waves on benthic diatoms of intertidal mudflats and intermittent rivers (Béchet et al. 2017). Finally, several contributions have shown that microphytobenthos research is still very active with several ongoing European research projects studying the factors driving biodiversity and the functioning of these benthic microbial communities (Koekodder et al. 2019; Prins et al. 2020), or the biodiversity and valorisation of the 'blue diatoms' (Poulin et al. 2019) and their marennine-like pigments (e.g. Gastineau et al. 2018).

A second session gave us the opportunity to hear about recent advances in environmental risk assessment with a critical review on biofilm-based omics approaches (Larras et al. 2018, 2020; Feio et al. 2020). This was confronted to current studies within the European Water Framework Directive (WFD) implementation: improvements of existing indices are foreseen through the revision of diatom autoecological profiles or the inclusion of epibiotic assemblages (Vassal et al. 2020) while new indices are under development for overseas territories or water bodies other than rivers (lakes). Besides this policy framework, several contributions dealt with the diversity and distribution of diatoms assemblages over the world, e.g. in the global ocean (Benoiston et al. 2017) or in Antarctica freshwater lakes, thereby illustrating the usefulness of these organisms for understanding general patterns governing community species assembly across ecosystems. Diatom biodiversity and phylogenetic studies (Lewitus et al. 2018) can also help in reconstructing paleo-environment or even more 
recent historical events, as shown by a striking contribution documenting diatoms found on the hair of Holy Mary-Magdalene relics (Morin et al. 2020).

Tradition has it that, a last session was dedicated to diatom taxonomy based on the morphology and ornamentation of their silicified exoskeleton (frustule), with a significant contribution to this knowledge by non-academic experts. In particular, three new species of Surirella (Liu et al. 2020) and Punctastriata (Wetzel and Ector 2020) were described while the study of Heudre et al. (2020) focused on the rarely described flora of continental brackish ecosystems.

\section{Acknoledgements}

ML thanks the ADLaF organization comity and in particular Laura Moreau, David Heudre, Catherine Pierson and Aude Beauger for their strong support. Financial support was provided by Université de Lorraine, CNRS, Région Grand-Est, DREAL Grand-Est, Metz Métropole and Office Français de la Biodiversité (OFB). ML also warmly thanks Benoît Schoefs for the edition of this Special Issue and Jérôme Anfré for the artwork.

\section{References}

Allen, J, M Laviale, M Cellamare, Q Bachelet, V Felten, M Danger. 2020. Do leaf-litter decomposers control biofilm primary production and benthic algal community structure in forest streams? Insights from an outdoor mesocosm experiment. Freshwat Biol. https://doi.org/10.1111/fwb.13475

Béchet, Q, M Laviale, N Arsapin, H Bonnefond, O Bernard. 2017. Modeling the impact of high temperatures on microalgal viability and photosynthetic activity. Biotechnol Biofuels. 10(1):136. doi:10.1186/s13068-017-0823-z

Benoiston, A-S, FM Ibarbalz, L Bittner, L Guidi, O Jahn, S Dutkiewicz, C Bowler. 2017. The evolution of diatoms and their biogeochemical functions. Phil Trans R Soc B. 372(1728):20160397. doi:10.1098/rstb.2016.0397

Contreras, JA, JTF Gillard. 2020. Asparagine-based production of hydrogen peroxide triggers cell death in the diatom Phaeodactylum tricornutum. Bot Lett.

Crenier, C, J Arce-Funck, A Bec, E Billoir, F Perrière, J Leflaive, F Guérold, V Felten, M Danger. 2017. Minor food sources can play a major role in secondary production in detritus-based ecosystems. Freshwat Biol. 62 (7):1155-1167. doi:10.1111/fwb.12933 
Feio, MJ, SRQ Serra, A Mortágua, A Bouchez, F Rimet, V Vasselon, SFP Almeida. 2020. A taxonomy-free approach based on machine learning to assess the quality of rivers with diatoms. Sci Tot Environ. 722:137900. doi:10.1016/j.scitotenv.2020.137900

Gastineau, R, F Prasetiya, C Falaise, B Cognie, P Decottignies, M Morançais, V Méléder, N Davidovich, F Turcotte, R Tremblay, et al. 2018. Blue technologies: production and use of marine molecules. Weinheim (Germany): Wiley-VCH Verlag GmbH \& Co. KGaA. Marennine-like Pigments: Blue Diatom or Green Oyster Cult?; p. 527-550. doi:10.1002/9783527801718.ch16

Heudre, D, CE Wetzel, B Van de Vijver, L Moreau, L Ector. 2020. Brackish diatom species (Bacillariophyta) from rivers of Rhin-Meuse basin in France. Bot Lett.

Koedodder, C, W Stock, A Willems, S Mangelinckx, M De Troch, W Vywerman, K Sabbe. 2019. Diatom-bacteria interactions modulate the composition and productivity of benthic diatom biofilms. Front Microbiol. 10:1255. doi:10.3389/fmicb.2019.01255

Larras, F, E Billoir, S Scholz, M Tarkka, T Wubet, S-JM Delignette-Muller M-L. 2020. A multi-omics concentration-response framework uncovers novel understanding of triclosan effects in the chlorophyte Scenedesmus vacuolatus. J Haz Mat. 397:122727. doi:10.1016/j.jhazmat.2020.122727

Larras, F, E Billoir, V Baillard, A Siberchicot, S Scholz, T Wubet, M Tarkka, M Schmitt-Jansen, M-L Delignette-Muller. 2018. DRomics: A turnkey tool to support the use of the dose-response framework for Omics data in ecological risk assessment. Environ Sci Technol. 52(24):14461-14468. doi:10.1021/acs.est.8b04752

Laviale, M, A Beaussart, J Allen, F Quilès, S El-Kirat-Chatel. 2019a. Probing the adhesion of the common freshwater diatom Nitzschia palea at the nanoscale. ACS Appl Mater Interfaces. 11(51):48574-48582. doi:10.1021/acsami.9b17821

Laviale, M, D Heudre, L Moreau, S Morin, editors. 2019b Sep 10-12. Programme and abstract book, 38th ADLaF meeting. Metz (France). French. https://hal.archivesouvertes.fr/hal-02549502.

Lewitus, E, L Bittner, S Malviya, C Bowler, H Morlon. 2018. Clade-specific diversification dynamics of marine diatoms since the Jurassic. Nat Ecol Evol. 2(11):1715-1723. doi:10.1038/s41559-018-0691-3 
Liu, B, P Kociolek, L Ector. 2020. Surirella dongtingensis sp. nov. and ultrastructure of S. undulata (Bacillariophyta) from China. Bot Lett.

Fadhlaoui, M, V Laderriere, I Lavoie, C Fortin. 2020. Influence of temperature and nickel on algal biofilm fatty acid composition. Environ. Toxicol. Chem. doi.org/10.1002/etc.4741

Morin, S, F Straub, R Weil, P Charlier. 2020. Diatoms on the hair of Holy MaryMagdalene relics. Bot Lett.

Poulin, M, V Méléder, J-L Mouget. 2019. Typification of the first recognized blue pigmented diatom, Haslea ostrearia (Bacillariophyceae). Plant Ecol Evol. 152(2):402-408. doi:10.5091/plecevo.2019.1622

Prins, A, P Deleris, C Hubas, B Jesus. 2020. Effect of light intensity and light quality on diatom behavioral and physiological photoprotection. Front Mar Sci. 7:203. doi:10.3389/fmars.2020.00203

Vassal, V, L Ector, B Van de Vijver, V Roubeix, A Olivier, S Pauvert, C Roy, S Fayolle. 2020. Pond turtle carapaces, an alternative natural substrate for the use of a diatom-based water quality index. Bot Lett.

Wetzel, CE, L Ector. Forthcoming. Two new Puncastriata (Bacillariophyta) species from subalpine French lakes. Bot Lett. 